\title{
Analysis of Actinobacteria from mould-colonized water damaged building material
}

\author{
Jenny Schäfer ${ }^{\mathrm{a}}$, Udo Jäckel ${ }^{\mathrm{b}}$, Peter Kämpfer ${ }^{\mathrm{a}, *}$ \\ a Justus-Liebig Universität Giessen, Institut für Angewandte Mikrobiologie, Heinrich-Buff-Ring 26-32, 35392 Giessen, Germany \\ b Bundesanstalt für Arbeitsschutz und Arbeitsmedizin, Nöldner Strasse 40-42, 10317 Berlin, Germany
}

\begin{abstract}
A B S T R A C T
Mould-colonized water damaged building materials are frequently co-colonized by actinomycetes. Here, we report the results of the analyses of Actinobacteria on different wall materials from water damaged buildings obtained by both cultivation-dependent and cultivation-independent methods. Actinobacteria were detected in all but one of the investigated materials by both methods. The detected concentrations of Actinobacteria ranged between $1.8 \times 10^{4}$ and $7.6 \times 10^{7} \mathrm{CFU} \mathrm{g}^{-1}$ of investigated material. A total of 265 isolates from 17 materials could be assigned to 31 different genera of the class Actinobacteria on the basis of 16S rRNA gene sequence analyses. On the basis of the cultivation-independent approach, $16 \mathrm{~S}$ rRNA gene inserts of 800 clones (50\%) were assigned to 47 different genera. Representatives of the genera Streptomyces, Amycolatopsis, Nocardiopsis, Saccharopolyspora, Promicromonospora, and Pseudonocardia were found most frequently. The results derived from both methods indicated a high abundance and variety of Actinobacteria in water damaged buildings. Four bioaerosol samples were investigated by the cultivation-based approach in order to compare the communities of Actinobacteria in building material and associated air samples. A comparison of the detected genera of bioaerosol samples with those directly obtained from material samples resulted in a congruent finding of 9 of the overall 35 detected genera (25\%), whereas four genera were only detected in bioaerosol samples.
\end{abstract}

\section{Introduction}

The visible colonisation of water damaged building materials by microorganisms is often associated with the growth of moulds. Hence, microbiological investigations are focused on these eukaryotic microorganisms. Consequently, Aspergillus versicolor, Stachybotrys chartarum or Penicillium chrysogenum have been described as the predominant species and bio-indicators for water damage in building materials [10]. In addition to the material damage caused by microbial growths, they are associated with several negative health effects, such as coughing, wheezing, asthma, airway infections, tiredness and headaches $[8,13,50,53]$. Until now, however, no clear proof has been provided for a causal connection of the fungal species present, or their metabolites, and the reported negative health effects [54].

Apart from moulds, several authors $[2,17,30,38]$ have reported co-colonisation of water damaged materials by actinomycetes. For example, Lorenz et al. [31] showed the presence of actinomycetes in $61 \%$ of 561 materials examined. They detected members of the genera Nocardia, Nocardiopsis, Streptomyces, Pseudonocardia

\footnotetext{
* Corresponding author.

E-mail address: Peter.Kaempfer@umwelt.uni-giessen.de (P. Kämpfer).
}

and Promicromonospora. Recently, Suihko et al. [52] also reported the presence of actinobacteria in $29 \%$ of 52 materials investigated. These observations confirmed earlier results $[4,6,38]$. In addition, Hyvärinen et al. [17] detected members of the genera Mycobacterium, Corynebacterium, Rhodococcus, Microbacterium and Arthrobacter.

Some Actinobacteria are known as biological agents that cause infections or allergic reactions $[28,34]$. For example, early investigations $[22,28,36]$ showed that Streptomyces albus, Saccharopolyspora rectivirgula or Mycobacterium immunogenum might cause a hypersensitivity pneumonitis. Due to the potential for infection of animals or humans, McNeil and Brown [34] described different Nocardia species as relevant for health. In addition, Streptomyces and Mycobacterium isolates from the indoor environment have been shown to produce cytotoxic metabolites [3]. Toxicological analyses with these strains, for example, on mouse and human macrophages and on a mouse model, also showed cytotoxic effects and an inflammatory response $[14,15,20,21,43]$.

To date, neither the communities of Actinobacteria in water damaged building materials nor their impact on exposed inhabitants have been characterised in detail. Here, we report on the results of a comprehensive analysis of Actinobacteria from water damaged building materials. 
Table 1

Investigated material samples with the different parameters obtained.

\begin{tabular}{|c|c|c|c|c|c|c|c|c|}
\hline Sample no. & Object & $\begin{array}{l}\text { Year of } \\
\text { building }\end{array}$ & Material type & Room type, water damage & $\begin{array}{l}\text { Estimated age of } \\
\text { water damage }\end{array}$ & $\begin{array}{l}\text { Room } \\
\text { temperature }\end{array}$ & Humidity $^{\mathrm{a}}$ & pH-value ${ }^{b}$ \\
\hline P1 & 01 & 1900 & Plaster & Cellar fault, outer wall & Old & $9.9^{\circ} \mathrm{C}$ & $100 \%$ & 7.0 \\
\hline P2 & 06 & 1971 & Plaster & $\begin{array}{l}\text { Ground floor, kitchen, but } \\
\text { damage in bathroom }\end{array}$ & Old & $21.9^{\circ} \mathrm{C}$ & $88.3 \%$ & 6.3 \\
\hline P3 & 07 & $\begin{array}{l}\text { n.k., old } \\
\text { building }\end{array}$ & Plaster & $\begin{array}{l}\text { First floor, kitchen, outer } \\
\text { wall, crack of facade }\end{array}$ & Presumably old & $21.1^{\circ} \mathrm{C}$ & $99.7 \%$ & 8.0 \\
\hline P4 & 08 & 1991 & Plaster & $\begin{array}{l}\text { Between corridor and } \\
\text { bathroom, } \\
\text { Leakage next to the shower }\end{array}$ & Presumably $<2$ years & $19.0^{\circ} \mathrm{C}$ & $97.9 \%$ & 8.4 \\
\hline P5 & 09 & 1920 & Plaster & $\begin{array}{l}\text { Ground floor, bedroom, } \\
\text { outer wall, presumed } \\
\text { hydro-thermal effects }\end{array}$ & Very old & $14.7^{\circ} \mathrm{C}$ & $72.1 \%$ & 7.5 \\
\hline P6 & 11 & $1960 \mathrm{~s}$ & Plaster & $\begin{array}{l}\text { Nursery, presumed } \\
\text { damage of drainage tube }\end{array}$ & Presumably $<2$ years & $21.2^{\circ} \mathrm{C}$ & $66.8 \%$ & 6.8 \\
\hline P7 A/B & $12 \mathrm{~A} / \mathrm{B}$ & 1934 & Plaster & $\begin{array}{l}\text { First floor, nursery outer } \\
\text { wall, crack of facade }\end{array}$ & $<2$ years & $24.3-24.8^{\circ} \mathrm{C}$ & $93.7-96.7 \%$ & 7.0 \\
\hline $\mathrm{P} 8 \mathrm{~A} / \mathrm{B}$ & $15 \mathrm{~A} / 15 \mathrm{~B}$ & 1900 & Plaster & Basement, cellar, packing & Very old & $15.7^{\circ} \mathrm{C}$ & $90.2 \%$ & 7.4 \\
\hline P9 & 16 & ca. 1900 & Plaster & $\begin{array}{l}\text { Basement, cellar, outer } \\
\text { wall, packing }\end{array}$ & Very old & $15-17^{\circ} \mathrm{C}$ & $>90 \%$ & n.d. \\
\hline $\mathrm{S} 2 \mathrm{~A} / \mathrm{B}$ & $13 \mathrm{~A} / 13 \mathrm{~B}$ & 2005 & Styrofoam & $\begin{array}{l}\text { Ground floor, office, } \\
\text { flooring }\end{array}$ & New building & $20.1-21.1^{\circ} \mathrm{C}$ & $\begin{array}{l}\text { First } 93 \% \\
\text { Later 39\% }\end{array}$ & 7.0 \\
\hline M1 & 02 & 1982 & Insulation wool & $\begin{array}{l}\text { Basement, outer wall, } \\
\text { hydro-thermal effects }\end{array}$ & $<2$ years & $13-15^{\circ} \mathrm{C}$ & $40-60 \%$ & 9.0 \\
\hline $\mathrm{M} 2 \mathrm{~A} / \mathrm{B}$ & $04 / 04 \mathrm{~A}$ & 1954 & Mineral wool & $\begin{array}{l}\text { Nursery first floor } \\
\text { Hydro-thermal effects }\end{array}$ & Presumably old & $16.8^{\circ} \mathrm{C}$ & $59.7 \%$ & 11.3 \\
\hline M3 & 05 & 1971 & Mineral material & $\begin{array}{l}\text { Ground floor, bathroom, } \\
\text { burst pipe }\end{array}$ & Old & $20.4^{\circ} \mathrm{C}$ & $65.5 \%$ & 7.1 \\
\hline W1 & 14 & 1960 & Wallpaper & Basement, cellar, packing & $>2$ years & $22.1^{\circ} \mathrm{C}$ & $95.9 \%$ & 7.46 \\
\hline L1 & 10 & Before 1800 & Loam rendering & Ground floor, bathroom & Very old & $18.8^{\circ} \mathrm{C}$ & $82.9 \%$ & 9.3 \\
\hline
\end{tabular}

n.k., not known; n.d., not determined.

a $\mathrm{pH}$-values were measured in the laboratory, using a pH-electrode as well as pH-indicator paper.

b Humidity was measured on-site, using a measuring instrument (Almemo 2290-2) with a thermistor and sensor for moisture (FH A 646.1, Ahlborn, Holzkirchen).

\section{Materials and methods}

\section{Material sampling}

A total of 19 mould contaminated building materials were analysed from 16 different objects. Samples were collected in Germany from February 2006 to September 2007, and were distributed throughout the period. Materials were selected on the basis of the most influential parameters for microbial growth. Therefore, all the different parameters for the sampling sites were chosen to overcome limitations regarding the detection of Actinobacteria. Additionally, only mould contaminated and moisture damaged materials were taken for investigation because the growth of microorganisms depends to the highest degree on the availability of water, and the lowest water activity values $\left(a_{\mathrm{w}} \sim 0.65\right)$ are necessary to initiate microbial growth [12]. For this reason, no undamaged and dry material was investigated as a "negative control" because it could be expected that no, or only occasionally very few, actinobacteria would be detected. Furthermore, Górny [12] described Actinobacteria species as tertiary colonizers of building materials (after different fungi species) because of the necessarily high water content, and a study by Lorenz et al. [31] showed the sole occurrence of bacteria in only $1.8 \%$ of the analysed building material. Even regarding health relevance, investigation by Jaakkola et al. [18] showed that the risk of asthma was related to the presence of visible mould and/or mould odour in the workplace, but not to water damage or damp stains alone.

Details on material types, age of the houses, age of and reason for damage, as well as temperatures, dampness and $\mathrm{pH}$-values are given in Table 1. Samples were restricted to houses were health problems had been reported by the inhabitants. Samples were taken from building material with ethanol $(70 \%)$ cleaned tools.
Materials were homogenised, chopped and mixed for $10 \mathrm{~min}$ in glass receptacles. In four rooms, bioaerosol samples were collected in parallel. Bioaerosols from 100 to $200 \mathrm{~L}$ of room air were collected by impaction using the MAS 100 (Merck, Darmstadt) on three different solid media: actinomycetes isolation agar (Difco, USA), mineral agar according to Gauze et al. [11], and brain heart infusion agar (Difco, USA).

\section{Isolation}

Before cultivation, cells were collected in suspension from material by shaking ( $15 \mathrm{~min}$ at $500 \mathrm{rpm})$ the material in a solution (10-fold by weight) of $0.9 \% \mathrm{NaCl}$ and $0.01 \%$ Tween 80 . Subsequently, the cell suspensions were diluted in a tenfold dilution series up to $10^{5}$. From all dilutions, three agar plates were inoculated by plating $0.1 \mathrm{~mL}$ of the corresponding suspension on each of the following media: actinomycete isolation agar (Difco, USA), mineral agar according to Gauze et al. [11], brain heart infusion agar (Difco, USA), casein mineral agar [1] and tryptone soy agar (Becton Dickinson, Heidelberg). For inhibition of moulds, $0.1 \mathrm{~g} \mathrm{~L}^{-1}$ natamycin-concentrate (86-93\%, AddFood, Ascheberg) was added. All colonies showing different appearances were quantified by counting and then transferred to another agar plate containing subcultivation media. For subcultivation, four different media, ISP-2 agar, ISP-3 agar [49], M79 agar [40] and brain heart infusion agar (Difco, USA), were used. All plates were incubated for 10-21 days at $28^{\circ} \mathrm{C}$.

From all isolates with morphological and microscopic similarities only one "reference isolate" was chosen and studied in more detail. These bacterial isolates were stored at $-20^{\circ} \mathrm{C}$ and $-80^{\circ} \mathrm{C}$ in $0.5 \mathrm{~mL}$ newborn bovine serum (Bio Wittaker ${ }^{\mathrm{TM}}$, Belgium). Colony forming units (CFU) per gram fresh weight were calculated from 
the numbers of all different colonies that were determined as actinobacterial isolates.

\section{DNA extraction and PCR amplification}

\section{DNA extraction and PCR amplification from bacterial DNA of the} isolates

For genomic DNA extraction from objects 1 to 4 (samples P1, M1, S1, M2; Table 1), a loopful of bacterial cells was transferred into a reaction tube $(1.5 \mathrm{~mL})$. After disruption of cells by a 1 min beadbeating step (Retsch, Haan) with $1 \mathrm{~g}$ of $0.1 \varnothing$ Zirconia beads (Carl Roth $\mathrm{GmbH}+\mathrm{Co}$, Karlsruhe) at maximum speed, the DNA extraction steps were performed with the GenElute ${ }^{\mathrm{TM}}$ Plant Genomic DNA Kit (Sigma), following the instructions of the manufacturer. The 16S rRNA genes were analysed as described by Kämpfer et al. [26]. DNA extraction and PCR-amplification of isolates from objects 5 to 16 (Table 1) were carried out by SMB, Services in Molecular Biology, Rüdersdorf.

\section{DNA extraction and PCR amplification from building material} samples

Total DNA was extracted directly from 0.05 to $0.5 \mathrm{~g}$ building material using the FastDNA ${ }^{\circledR}$ Spin Kit for soil (MP Biomedicals), following the manufacturer's instructions. For each DNA extraction, a negative control was carried out to ensure the purity of all solutions in the extraction kit. The successfully extracted DNA was used for further PCR and cloning analysis.

PCR was performed in a total volume of $50 \mu \mathrm{L}$, prepared in parallel using universal bacteria primers (27f, 1492r) targeting the $16 \mathrm{~S}$ rRNA gene [29,59]. The PCR assay contained 5.0 $\mu \mathrm{L}$ PCR-buffer, $4 \mu \mathrm{L}$ $\mathrm{MgCl}_{2}(25 \mathrm{mM}), 5 \mu \mathrm{L}$ dNTPs $(2 \mathrm{mM}), 1 \mu \mathrm{L}$ of each primer $(10 \mu \mathrm{M}$, MWG Biotech, Ebersberg, Germany), 31.6 $\mu$ L RNAse and DNAse free water (Invitrogen, Carlsbad, CA), $0.2 \mu \mathrm{L}$ BSA ( $20 \mathrm{mg} \mathrm{mL}^{-1}$ ), $0.2 \mu \mathrm{L}$ Taq-polymerase $\left(5 \mathrm{U} \mathrm{LL}^{-1}\right)$ (all MBI Fermentas, St.Leon Rot) and $2 \mu \mathrm{L}$ DNA extract. PCR was carried out in a Thermocycler (My Cycler ${ }^{\mathrm{TM}}$, BioRad, München, Germany) with an initial denaturation step at $95^{\circ} \mathrm{C}$ for $3 \mathrm{~min}$, followed by 29 cycles of $1 \mathrm{~min}$ at $94^{\circ} \mathrm{C}$, $45 \mathrm{~s}$ at $57.3^{\circ} \mathrm{C}$, and $2 \mathrm{~min}$ at $72^{\circ} \mathrm{C}$, followed by a final extension at $72^{\circ} \mathrm{C}$ for $30 \mathrm{~min}$. PCR was purified by QiaQuick PCR Purification Kit (Qiagen, Hilden) and quantified photometrically (Ultrospec 4000, Amersham Biosciences, Freiburg).

Due to the low amounts of PCR products from the DNA of samples M1 and M2, a nested PCR was performed. First, a PCR using primers 616v [AGAGTTTGATYMTGGCTCAG] and 118r [GGGTTYCCCCATTCGG] was prepared. The reaction mixture of $25 \mu \mathrm{L}$ contained $2.5 \mu \mathrm{L}$ PCR-buffer, $3 \mu \mathrm{L} \mathrm{MgCl}_{2}(25 \mathrm{mM}), 2.5 \mu \mathrm{L}$ dNTPs $(2 \mathrm{mM})$, $0.5 \mu \mathrm{L}$ of each primer ( $10 \mu \mathrm{M}$, MWG Biotech, Ebersberg, Germany), 16.2 $\mu \mathrm{L}$ RNAse and DNAse free water (Invitrogen, Carlsbad, CA), $0.2 \mu \mathrm{LBSA}\left(20 \mathrm{mg} \mathrm{mL}^{-1}\right), 0.1 \mu \mathrm{LTaq}$-polymerase $\left(5 \mathrm{U} \mathrm{LL}^{-1}\right)($ all MBI Fermentas, St.Leon Rot) and $1 \mu \mathrm{L}$ DNA extract. PCR was carried out in a Thermocycler (My Cycler ${ }^{\mathrm{TM}}$, BioRad, München, Germany) with an initial denaturation step at $95^{\circ} \mathrm{C}$ for $3 \mathrm{~min}$, followed by 30 cycles of $1 \mathrm{~min}$ at $94^{\circ} \mathrm{C}, 45 \mathrm{~s}$ at $57.3^{\circ} \mathrm{C}$, and $2 \mathrm{~min}$ at $72^{\circ} \mathrm{C}$, followed by a final extension at $72^{\circ} \mathrm{C}$ for $15 \mathrm{~min}$. Amplicons were purified by the QiaQuick PCR Purification Kit (Qiagen, Hilden) and subsequently aliquots were used in a PCR, as described above. A negative control analysis for PCR, containing nuclease free water instead of DNA, was always carried out.

\section{Cloning analysis and screening of generated clones by PCR}

For construction of clone libraries, the cloning kit Promega pGEM-T ${ }^{\circledR}$ Vector Systems (Maison, USA) was used according to the manufacturer's instructions. A total of 100 white colonies for each sample were randomly picked and incubated overnight at $37^{\circ} \mathrm{C}$ on LB agar containing ampicillin $\left(100 \mu \mathrm{g} \mathrm{mL}^{-1}\right), \mathrm{X}-\mathrm{Gal}\left(80 \mu \mathrm{g} \mathrm{mL}^{-1}\right)$, and IPTG $(100 \mathrm{mM})$ [42]. Inserts were re-amplified to screen all generated clones for affiliation to actinomycetes with two different Actinobacteria specific primer systems.

The first primer system, Com $2 x f$ (5'-AAACTCAAAGGAATTGACGG-3') [48, modified] and Ac1186 (5'-CTTCCTCCGAGTTGACCC$3^{\prime}$, developed in our group) was prepared to detect most actinobacteria. The reaction mixture of $25 \mu \mathrm{L}$ contained $2.5 \mu \mathrm{L}$ PCR-buffer, $2 \mu \mathrm{L} \mathrm{MgCl}_{2}$ ( $25 \mathrm{mM}$ ), $2.5 \mu \mathrm{L}$ dNTPs ( $2 \mathrm{mM}$ ), $0.5 \mu \mathrm{L}$ of each primer ( $10 \mu \mathrm{M}$, MWG Biotech, Ebersberg, Germany), $16.4 \mu \mathrm{L}$ RNAse and DNAse free water (Invitrogen, Carlsbad, CA), $0.2 \mu \mathrm{L}$ BSA (20 $\mathrm{mg} \mathrm{mL}^{-1}$ ) and $0.1 \mu \mathrm{L}$ Taq-polymerase $\left(5 \mathrm{U} \mathrm{LL}^{-1}\right.$ ) (all MBI Fermentas, St.Leon Rot). The reaction mixture was added directly to cells of the clones. PCR was also carried out in a Thermocycler (My Cycler $^{\mathrm{TM}}$, BioRad, München, Germany) with an initial denaturation step at $95^{\circ} \mathrm{C}$ for $3 \mathrm{~min}$, followed by 25 cycles of $30 \mathrm{~s}$ at $94^{\circ} \mathrm{C}, 30 \mathrm{~s}$ at $60^{\circ} \mathrm{C}$, and $30 \mathrm{~s}$ at $72^{\circ} \mathrm{C}$, followed by a final extension at $72^{\circ} \mathrm{C}$ for $15 \mathrm{~min}$. The second PCR using the primer system SC-Act235-aS20/SC-Act878-aA-19 [51] was carried out to increase the amount of detectable Corynebacteridae.

The PCR assay of $25 \mu \mathrm{L}$ contained $2.5 \mu \mathrm{L}$ PCR-buffer, $2.5 \mu \mathrm{L}$ $\mathrm{MgCl}_{2}(25 \mathrm{mM}), 2.5 \mu \mathrm{LdNTPs}(2 \mathrm{mM}), 0.5 \mu \mathrm{L}$ of each primer $(10 \mu \mathrm{M}$, MWG Biotech, Ebersberg, Germany), $16.35 \mu \mathrm{L}$ RNAse and DNAse free water (Invitrogen, Carlsbad, CA), $0.2 \mu \mathrm{LBSA}\left(20 \mathrm{mg} \mathrm{mL}^{-1}\right.$ ) and $0.15 \mu \mathrm{L}$ Taq-polymerase $\left(5 \mathrm{U}_{\mu L^{-1}}\right.$ ) (all MBI Fermentas, St.Leon Rot). The reaction mixture was also added directly to cells of the clones. PCR was performed with an initial denaturation step at $95^{\circ} \mathrm{C}$ for $4 \mathrm{~min}$, followed by $25 \mathrm{cycles}$ of $30 \mathrm{~s}$ at $95^{\circ} \mathrm{C}, 1 \mathrm{~min}$ at $70^{\circ} \mathrm{C}$, and $2 \mathrm{~min}$ at $70^{\circ} \mathrm{C}$, followed by a final extension at $72^{\circ} \mathrm{C}$ for $15 \mathrm{~min}$. A control PCR with PCR reagents was always carried out. The PCR products were visually evaluated by $1 \%$ agarose gel electrophoresis with ethidium bromide staining. All "positive" detected clones, meaning a PCR product with at least one primer system, were recultured in LB broth, and aliquots were preserved at $-80^{\circ} \mathrm{C}$ in $99 \%$ glycerol in a $1: 3$ mixture [44].

\section{Sequencing and analysis of the results}

\section{Sequencing and analysis of the 16S rRNA gene sequences of the} isolates

Sequencing of the 16S rRNA genes of the isolates was carried out by Services in Molecular Biology (Rüdersdorf). The sequences were performed and aligned by comparison with similar sequences using the software package MEGA (Molecular Evolutionary Genetics Analysis) version 4 [55]. Similarity searches against the NCBI database were carried out using a BLAST search (http://www.ncbi.nlm.nih.gov/). Multiple sequence alignment with type strains of the detected genera, as well as genetic distance calculations (distance options according to the Kimura 2parameter model) of the data were also performed using MEGA 4.0. Phylogenetic trees were constructed by the neighbour-joining method using bootstrap values based on 1000 replications. The 16S rRNA gene sequences of isolates and clones reported in the present study were deposited in the GenBank database. Accession numbers are given in the phylogenetic trees (supplementary Figs. S1-S8) and Table 2 under the following accession numbers GU573980-GU574174 and GU594673-GU594680.

\section{Sequencing and phylogenetic analysis of $16 S \mathrm{rRNA}$ gene sequences} from clone-inserts

The clone colonies were dispatched on LB agar plates to Services in Molecular Biology (Rüdersdorf), where sequencing was carried out. For sequencing, the M13f or M13r sequencing primer (Invitrogen, Carlsbad, CA) was used, resulting in a sequence length of approximately $400 \mathrm{bp}$. Similarity searches against the NCBI database were performed using a BLAST search (http://www.ncbi.nlm.nih.gov/). Phylogenetic trees were constructed only with $16 \mathrm{~S}$ rRNA gene sequences $>1300$ bp by the 
Table 2

Isolate and clone sequence most closely related to bacteria assigned to risk group 2, according to TRBA 466 .

\begin{tabular}{|c|c|c|c|c|}
\hline Isolate/clone (accession no.) & Most closely related species & Sequence similarity ${ }^{\mathrm{a}}$ & Accession no. & Risk group \\
\hline 02-Gi-019 (GU574174) & Corynebacterium amycolatum & $99.40 \%$ & X82057 & 2 \\
\hline 01-Gi-005 (GU574063) & Mycobacterium flavescens & $98.40 \%$ & X52932 & 2 \\
\hline 05-Be-043 (GU574173) & Mycobacterium wolinskyi & $98.80 \%$ & Y12873 & 2 \\
\hline 07-St-010 (GU574130) & Nocardiopsis dassonvillei subsp. albirubida & $100 \%$ & X97882 & 2 \\
\hline 05-St-001 (GU574122) & Nocardiopsis dassonvillei & $100 \%$ & X97886 & 2 \\
\hline 05-Be-009 (GU574123) & Nocardiopsis dassonvillei & $99.90 \%$ & X97886 & 2 \\
\hline P2-S-DW11-16 clone (GU574058) & Propionibacterium granulosum & $99.50 \%$ & AJ003057 & 2 \\
\hline
\end{tabular}

a Multiple alignment, distances (distance options according to the Kimura 2-parameter model) were performed by using the software package MEGA (Molecular Evolutionary Genetics Analysis) version 4 [55].

neighbour-joining method, using bootstrap values based on 1000 replications (together with the sequences of the isolates).

\section{Results}

\section{Concentration}

To investigate the actinobacterial communities in water damaged buildings, 19 material samples and 4 bioaerosol samples from 16 objects were investigated. Actinobacteria were detected in 18 out of 19 investigated material samples by cultivation-based and/or by molecular methods (Table 1). Bacterial growth could not be detected in Styrofoam sample S2B. The concentration of cultivable Actinobacteria in bioaerosol samples varied between $4.7 \times 10^{2} \mathrm{CFU} \mathrm{m}^{-3}$ and $8.5 \times 10^{2} \mathrm{CFU} \mathrm{m}^{-3}$. The concentration of Actinobacteria in investigated materials varied between $1.8 \times 10^{4} \mathrm{CFU} \mathrm{g} \mathrm{fw}^{-1}$ (gram fresh weight) and $3.4 \times 10^{7} \mathrm{CFU} \mathrm{g} \mathrm{fw}^{-1}$ in Styrofoam samples, between $7.8 \times 10^{5} \mathrm{CFU} \mathrm{g} \mathrm{fw}^{-1}$ and $7.6 \times 10^{7} \mathrm{CFU} \mathrm{g} \mathrm{fw}^{-1}$ in plaster samples, and between $4.4 \times 10^{4} \mathrm{CFU} \mathrm{g} \mathrm{fw}^{-1}$ and $4.1 \times 10^{6} \mathrm{CFU} \mathrm{g} \mathrm{fw}^{-1}$ in mineral material. The concentration detected in wallpaper and loam rendering was $1.7 \times 10^{5} \mathrm{CFU} \mathrm{g} \mathrm{fw}^{-1}$ and $3.7 \times 10^{5} \mathrm{CFU} \mathrm{g} \mathrm{fw}^{-1}$, respectively (Fig. 1).

Isolates

From all samples (material and bioaerosol samples), a total of 419 isolates were obtained. Multiple isolated bacteria were grouped according to the colony and cell morphology, as well as Gram staining. From one representative isolate of each group $(n=334)$, the 16S rRNA gene was sequenced. Based on 16S rRNA gene sequence analyses, 293 isolates were assigned to the class Actinobacteria and 17 isolates to the Alphaproteobacteria or Firmicutes. Some isolates $(n=24)$ could not be identified because subcultivation failed. The actinobacterial isolates were representatives of 35 different genera, of which species of Streptomyces $(n=94 / 32.1 \%$ ), Amycolatopsis $(n=20 / 6.8 \%)$, Nocardiopsis $(n=20 / 6.8 \%)$, Nocardia $(n=15 / 5.1 \%)$, Pseudonocardia $(n=21 / 7.2 \%)$, Saccharopolyspora $(n=13 / 4.4 \%)$ and Promicromonospora $(n=16 / 5.5 \%)$ were found most frequently. Seven isolates were assigned to the genus Mycobacterium. In total, seven species closely related to bacteria of risk group 2 were detected (Table 2 ).

\section{Clone libraries}

In addition to the cultivation-based approaches, the Actinobacteria populations were also analysed in this study by the generation of 16S rRNA gene clone libraries. From 1587 generated clones, approximately $50 \%(n=800)$ showed specific PCR products using Actinobacteria specific primers. Depending on the investigated material, the proportion of "Actinobacteria positive clones" varied between $8.7 \%$ and $88.5 \%$ (Fig. 2). After partial sequence analysis, 47 different genera of the class Actinobacteria were detected. The most abundant genera were Amycolatopsis $(n=134 / 16.8 \%)$, Arthrobac$\operatorname{ter}(n=48 / 6.0 \%)$, Jiangella $(n=33 / 4.1 \%)$, Nesterenkonia $(n=44 / 5.5 \%)$, Promicromonospora ( $n=59 / 7.4 \%)$, Pseudonocardia $(n=121 / 15.1 \%)$,

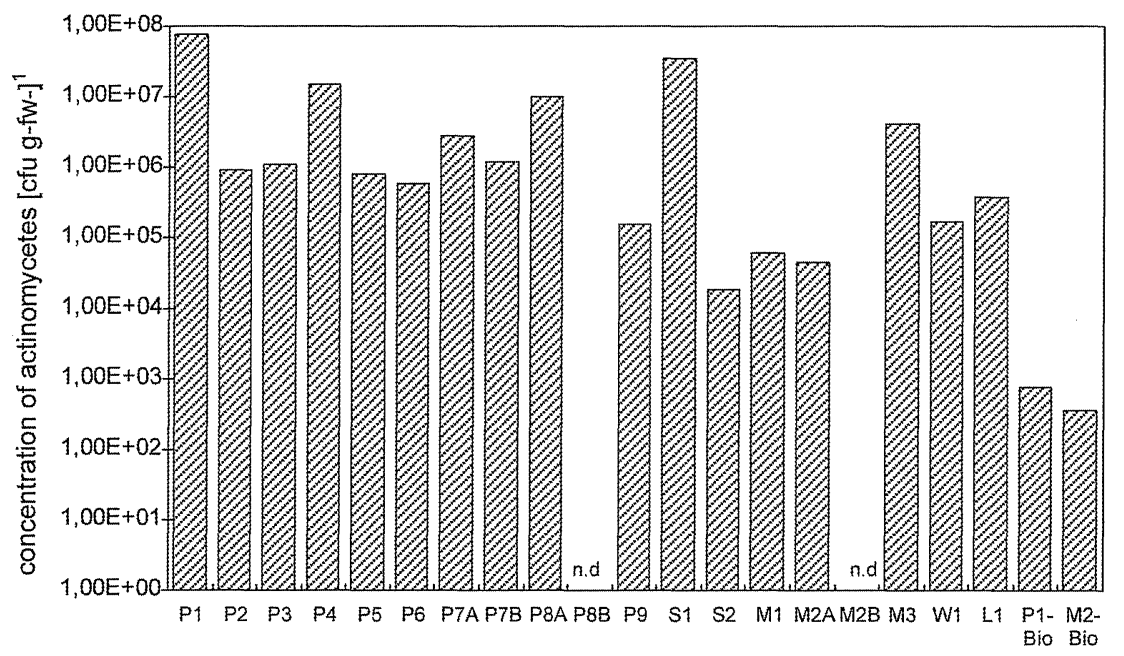

Fig. 1. Concentrations of Actinobacteria in CFU g ${ }^{-1} \mathrm{fw}_{\left(\mathrm{m}^{-3}\right)}$ of investigated material samples (17) and bioaerosol samples (2). Values represent results of single analyses. n.d., not determined. 


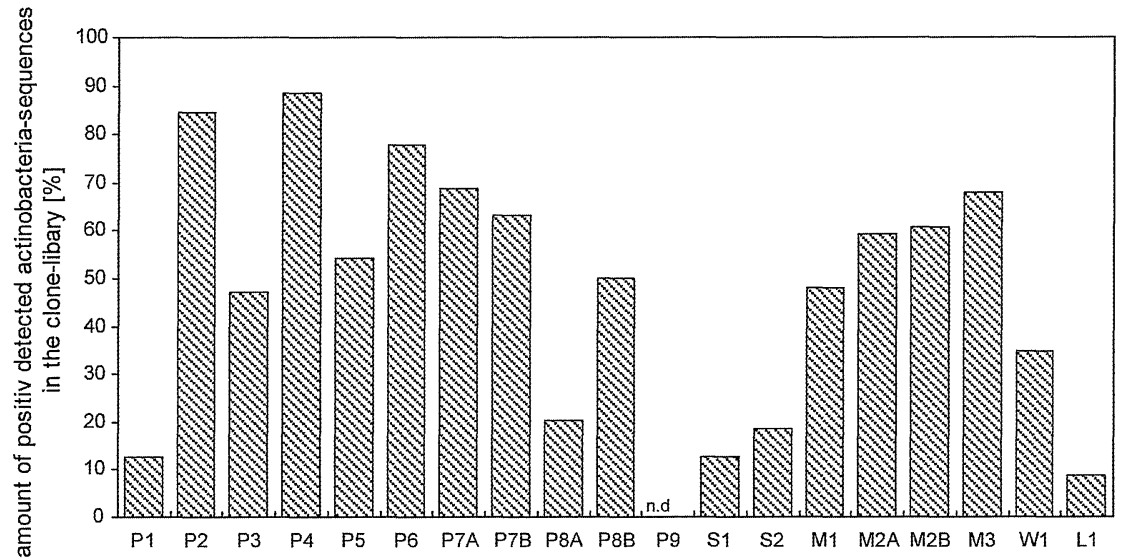

Fig. 2. Amount of detected actinobacteria clones (\%) from analysed material samples. Values represent results of single analyses. n.d., not determined.

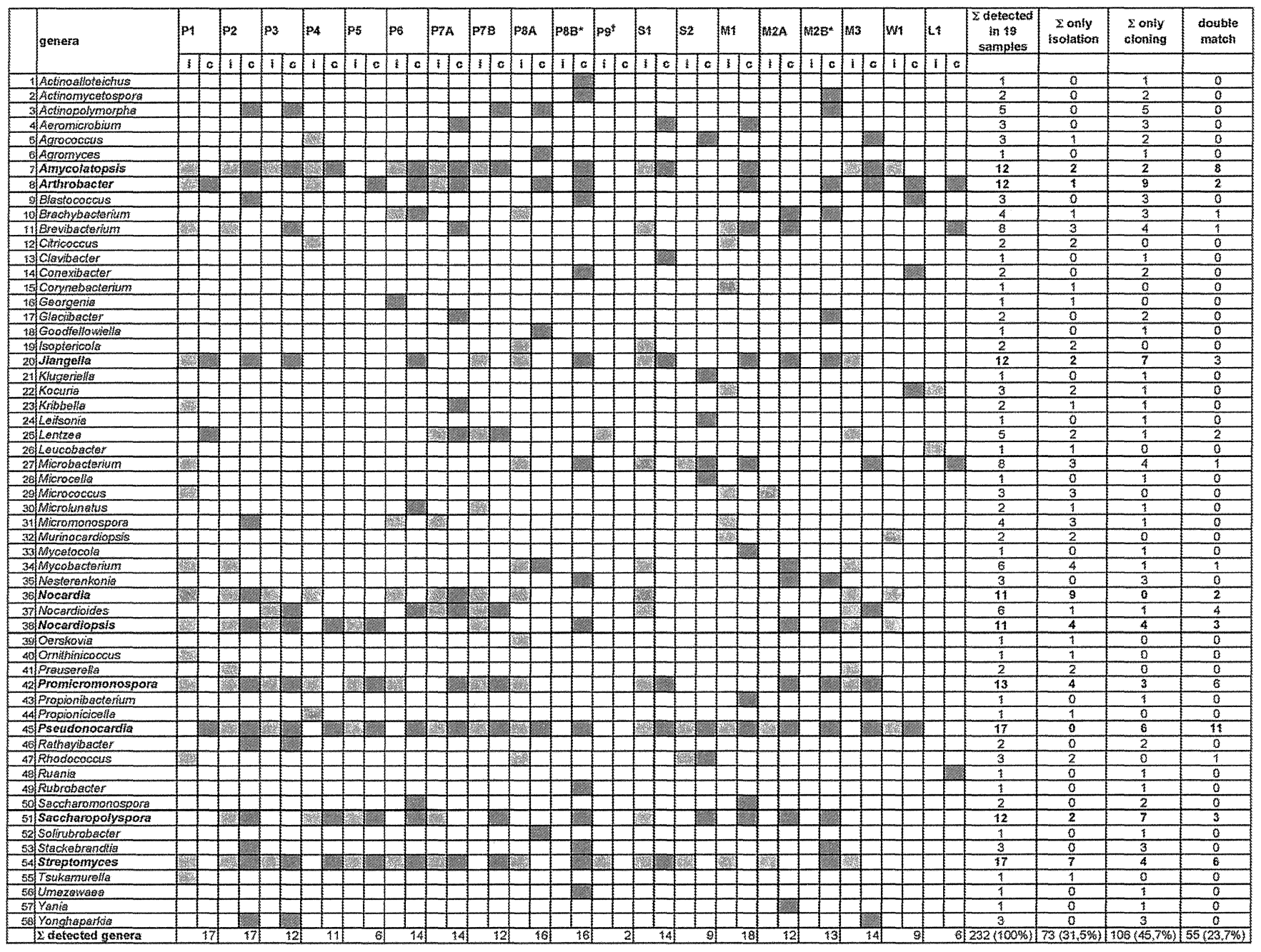

Fig. 3. Abundance of clones and isolates. Distribution of the clones and isolates in taxonomic genera and their abundance in the individual samples are displayed in columns 1-19. The light grey shading indicates a match via isolation; the dark grey shading indicates a match by cloning analyses in the sample belonging to the respective genera. White cells indicate no match. Column 20 shows the number of samples in which the different genera were detected. Columns 21 and 22 show the number of samples in which different genera were detected only by isolation or cloning analyses, whereas in column 23 the number of samples is listed in which genera were detected by both cultivation and cloning analyses; ${ }^{*}$ Only investigated by cloning analyses; ${ }^{\dagger}$ only investigated by isolation analyses; $\mathrm{i}=\mathrm{isolation} ; \mathrm{c}=\mathrm{cloning}$ analyses. 
Table 3

Comparison of detected genera in material and bioaerosol samples, number of isolates within the genera with sequence similarities $>99 \%$ are given in parentheses ${ }^{\mathrm{a}}$.

\begin{tabular}{|c|c|c|}
\hline Bioaerosol sample & Material sample & $\begin{array}{l}\text { Material and } \\
\text { bioaerosol sample }\end{array}$ \\
\hline $\begin{array}{l}\text { Indoor object } 1 \text { (sar } \\
\text { Janibacter } \\
\text { Kocuria } \\
\text { Pseudonocardia }\end{array}$ & $\begin{array}{l}\text { Amycolatopsis } \\
\text { Brevibacterium } \\
\text { Jiangella } \\
\text { Kribella } \\
\text { Microbacterium } \\
\text { Micrococcus } \\
\text { Mycobacterium } \\
\text { Nocardia } \\
\text { Nocardia } \\
\text { Ornithinimicrobium } \\
\text { Promicromonospora } \\
\text { Tsukamurella }\end{array}$ & $\begin{array}{l}\text { Arthrobacter } \\
\text { Nocardiopsis (1) } \\
\text { Rhodococcus } \\
\text { Streptomyces(2) }\end{array}$ \\
\hline $\begin{array}{l}\text { Indoor object } 2 \text { (san } \\
\text { Arsenicicoccus } \\
\text { Kytococcus }\end{array}$ & $\begin{array}{l}\text { Brevibacterium } \\
\text { Citricoccus } \\
\text { Corynebacterium } \\
\text { Kocuria } \\
\text { Micrococcus } \\
\text { Micromonospora } \\
\text { Pseudonocardia }\end{array}$ & $\begin{array}{l}\text { Nocardiopsis } \\
\text { Saccharopolyspora } \\
\text { Streptomyces }(1)\end{array}$ \\
\hline $\begin{array}{l}\text { Indoor object } 3 \text { (san } \\
\text { Actinomadura } \\
\text { Micrococcus } \\
\text { Rhodococcus }\end{array}$ & $\begin{array}{l}\text { Amycolatopsis } \\
\text { Isoptericola } \\
\text { Jiangella } \\
\text { Microbacterium } \\
\text { Mycobacterium } \\
\text { Nocardioides } \\
\text { Promicromonospora } \\
\text { Pseudonocardia }\end{array}$ & $\begin{array}{l}\text { Brevibacterium(1) } \\
\text { Nocardia(1) } \\
\text { Streptomyces(1) }\end{array}$ \\
\hline Indoor object 4 (san & Pseudonocardia & $\begin{array}{l}\text { Micrococcus(1) } \\
\text { Streptomyces }\end{array}$ \\
\hline
\end{tabular}

a Column 1 shows the indoor environment from where the material and bioaerosol samples were taken and listed the genera only detected in bioaerosol samples; column 2 shows the genera only detected in material samples; column 3 shows the genera which were detected in both the bioaerosol sample and the material sample.

Saccharopolyspora $(n=78 / 9.8 \%)$ and Streptomyces $(n=83 / 10.4 \%)$.

Comparison of cultivation-dependent and cultivation-independent methods

Overall, 58 different genera were detected within the 19 investigated water damaged samples (Fig. 3). Depending on the investigated material, the number of detected genera varied between 2 and 17 (mean=12) per material. The number of the "genera matches" in all samples was 232 . From these, $31.5 \%(n=73)$ and $45.7 \%(n=106)$ were detected exclusively by cultivation or by cloning analysis, respectively. In total, $23.7 \%(n=55)$ of the matches were detected by both methods in parallel. Independent of the method, the most frequently found genera were Pseudonocardia (detected in 17 samples out of 19 samples, 17/19), Streptomyces (17/19), Amycolatopsis (12/19), Saccharopolyspora (12/19), and Promicromonospora (13/19).

\section{Comparison of isolates from material and bioaerosol samples}

To investigate the actinobacterial communities in indoor air, four bioaerosol samples were investigated by the cultivation-based approach. All detected genera are listed in Table 3. Altogether, nine genera were detected both in bioaerosol and material samples, and four genera, Actinomadura, Arsenicicoccus, Janibacter and Kytococcus were only detected in bioaerosol samples. Comparison of the detected genera in material and corresponding bioaerosol samples resulted in a room dependent congruent finding of $20-66 \%$ at the genus level. 16S rRNA gene sequence similarities $>99 \%$ for isolates found both in bioaerosol samples and the corresponding material samples were detected in 8 out of 28 isolates (Table 3 ).

\section{Discussion}

Actinobacteria were detected in all but one of the investigated materials by both cultivation-dependent and cultivationindependent methods. In previous studies, Actinobacteria were reported in $18-70 \%$ of the investigated materials, dusts or bioaerosols of water damaged buildings, respectively $[17,31,37,52]$. All these results indicate the ubiquitous distribution of Actinobacteria in water damaged indoor environments.

Concentrations of Actinobacteria, cultivable using the applied media, varied between $1.8 \times 10^{4}$ and $3.4 \times 10^{7} \mathrm{CFU} \mathrm{g}^{-1}$ fresh weight in, for example, Styrofoam samples and to $\sim 8 \times 10^{7} \mathrm{CFU} \mathrm{g}^{-1}$ fresh weight in investigated plaster samples (Fig. 1). In comparison, investigations from Suihko et al. [52] showed approximate counts of filamentous actinobacteria and/or thermoactinomyctes of $10^{2}-10^{3} \mathrm{CFUg}^{-1}$ fresh weight in gypsum board, wallpaper or paint and plaster crumbs, and only higher counts of $10^{4}-10^{6} \mathrm{CFU}$ in insulator wool samples. Higher values of actinobacterial concentrations from our studies are similar to those found by FISH analyses in natural bulk soil habitats [60]. Therefore, the investigated building materials seem to offer similar good growth conditions for Actinobacteria species as soil. In contrast to soils, where Actinobacteria are assumed to represent only about $4 \%$ of the total bacterial community [19], investigations of clone libraries revealed their predominance in the studied materials. The amounts of detected actinobacterial 16S rRNA genes varied between 12.6 and $88.5 \%$ in clone libraries (Fig. 2). This has also been shown by Rintala et al. [42] in investigations of dust samples from an indoor environment with water damage, and they showed that $24 \%$ of the 16 S rRNA gene sequences obtained in generated clone libraries could be assigned to Actinobacteria.

Quite a high variety of the detected Actinobacteria was observed, with 58 different bacterial genera (Fig. 3) from 11 different (sub)-orders (Corynebacterineae, Frankineae, Glycomycineae, Micrococcineae, Micromonosporineae, Propionibacterineae, Pseudonocardineae, Rubrobacterineae, Solirubrobacterales, Streptomycineae and Streptosporangineae). In relation to case reports $[2,4,30,38,42,52,58]$, almost all of the genera detected in these studies were also found in our comprehensive approach. A comparison with the results of the study from Suhiko et al. [52], who investigated only filamentous Actinobacteria and thermoactinomycetes from 52 water damaged building materials using a cultivation-dependent approach, showed that much more genera were detectable in the present study. While these authors detected five different actinobacterial genera by cultivation of 122 isolates, our results from cultivation gave 31 different genera from 265 isolates from building material samples. These findings from Finland probably resulted from lower detectable concentrations of investigated materials, as well as lower occurrences (29\%) of Actinobacteria themselves. Furthermore, in the present study, 23 different genera were additionally detected by the cultivationindependent approach.

Some genera often detected in our study, for example, Amycolatopsis and Jiangella, have not been described as colonizers of water damaged indoor material to date. In addition, it was an interesting finding that although most of the isolates could be assigned to already described species, several of them could not be clearly assigned to any known species or even genera, and hence novel species and genera have been proposed, such as 
for example, Pseudonocardia parietis [45], Citricoccus parietis [46] Prauserella muralis [47], Promicromonospora umidemergens [33], Brevibacterium sandarkinum [23], Microlunatus parietis [25], Kytococcus aerolatus [24], and Murinocardiopsis flavida [27].

Genera detected in nearly $60 \%(\geq 11)$ of the investigated $(n=19)$ materials were Arthrobacter (12/19; detected in 12 samples out of 19 investigated samples), Promicromonospora (13/19), Pseudonocardia (17/19), Jiangella (12/19), Amycolatopsis (13/19), Nocardia (11/19), Saccharopolyspora (11/19), Nocardiopsis (12/19), and Streptomyces (17/19) (supplementary material, Figs. S1-S8). These genera may serve as actinobacterial indicators of water damage in buildings, like fungi such as A. versicolor, S. chartarum or P. chrysogenum.

In regard to identifying the most abundant species, $16 \mathrm{~S}$ rRNA gene sequence similarities to the sequences available in the databases indicate that these species were most closely related to Amycolatopsis palatopharyngis ( $>98.8 \%$ ) and Nocardia carnea $(>99.6 \%)$, which were both found in nine different materials. P. parietis sp. nov. [45] was detected in seven investigated materials. In addition, the species most closely related to Saccharopolyspora flava $(>97.8 \%)$ were detected in six different samples, and Nocardiopsis sp. (most closely related to Nocardiopsis dassonvillei, Nocardiopsis dassonvillei subsp. albirubida and Nocardiopsis synnemataformans) were also found in six different materials.

In the present study, members of the genus Streptomyces were detected in highest concentrations and in nearly all of the investigated materials (17/19), by both the cultivation-dependant and -independent approaches. This is essentially in agreement with earlier studies reporting Streptomyces in indoor environments $[3,41,43]$. Based on $16 \mathrm{~S}$ rRNA gene analyses, the intrageneric variety of Streptomyces isolates was high (the sequence allocations were scattered across the Streptomyces tree). Rintala et al. [41] detected 16S rRNA sequences most closely related to Streptomyces griseus, Streptomyces setonii, Streptomyces coelicolor, Streptomyces virginiae, Streptomyces sampsonii and Streptomyces rimosus, and Roponen et al. [43] described Streptomyces anulatus isolated from gypsum board. All these results showed a high abundance and high variety of Streptomyces species in water damaged materials.

Similar to the high abundance of Streptomyces, members of the genus Pseudonocardia were detected in 17 out of 19 investigated materials. Lorenz et al. $[30,32]$ described Pseudonocardia spp. from a plaster sample attached to some wall paper. In addition to Streptomyces, this genus may serve as a further indicator of water damage in an indoor environment. In the present study, the 16S rRNA gene sequences detected from isolates could be assigned to four sequence clusters most closely related to (i) P. parietis, (ii) a group of species comprising Pseudonocardia alni, Pseudonocardia carboxydivorans, Pseudonocardia antarctica, and (iii) two sequence clusters most closely related to Pseudonocardia ammonioxydans. 16S rRNA gene sequences of investigated clone libraries formed two further clusters which were most closely related to (i) Pseudonocardia spinosispora and (ii) Pseudonocardia petroleophila.

Similar negative health effects, as described for some Streptomyces spp., may be assumed for some Nocardiopsis species, which were detected in 12 out of 19 investigated materials. According to the "German" national classification list TRBA 466 [56], N. dassonvillei is classified into risk group (RG) 2 (RG 2: biological agents that can cause human disease and might be a hazard to workers). Four isolates were found to be most closely related to the two subspecies of $N$. dassonvillei. Peltola et al. [39] isolated Nocardiopsis exhalans (RG 1) from dust and reported cytotoxic effects for sperm cells, and Mehrer et al. [35] showed cytotoxicity of Nocardiopsis sp. towards swine kidney cells. Using cloning analyses, the presence of $N$. exhalans was also confirmed in our study but the majority of 20 isolated Nocardiopsis spp. were found to be most closely related to Nocardiopsis synemataformans and $N$. dassonvillei. In addition, representatives of genera less frequently detected, for example, Brevibacterium, Corynebacterium, Mycobacterium, Tsukamurella, Actinomadura, Microbacterium, Rhodococcus and Propionibacterium were detected as well. The detection of species from these genera confirmed earlier investigations $[5,38,42,57,58]$.

In particular, the genus Mycobacterium is of interest because several indications exist concerning its relevance in water damaged indoor environments. In this connection, Andersson et al. [5] detected Mycobacteria and related genera as major colonizers of a wall in a children's day care centre with visible moisture damage. Torvinen et al. [57] also described different potential pathogenic Mycobacteria isolated from water damaged building materials. Mycobacteria species are known to be responsible for different negative health effects, such as infections, inflammatory response, production of cytokines, NO and IL6 [16,21] and hypersensitivity pneumonitis [7,9]. In the present study, seven different Mycobacterium species were detected. Based on $16 \mathrm{~S}$ rRNA gene comparison, two isolates were most closely related to Mycobacterium flavescens and Mycobacterium wolinskyi. Both species are classified as biological agents of risk group 2 . Remaining isolates were most closely related to Mycobacterium moriokaense $(n=2)$, Mycobacterium tusciae, Mycobacterium septicum and Mycobacterium alvei, which are classified as biological agents of risk group 1 .

Infections or allergic reactions can only occur after direct contact with relevant pathogens. To investigate a potential release of bacteria from water damaged material we compared the actinobacterial communities in bioaerosols and the corresponding water damaged materials from four rooms. From $20 \%$ to $66 \%$ of the detected genera were congruent. In both bioaerosol and material samples, representatives of the genera Arthrobacter, Brevibacterium, Kocuria, Micrococcus, Nocardia, Nocardiopsis, Pseudonocardia, Rhodococcus and Streptomyces were detected (Table 3). On the basis of a 16S rRNA gene sequence similarity $>99 \%$ from 28 isolates, 8 isolates (28\%) from bioaerosols were also found in the material samples. Most of the members of the genera listed above are able to produce aerial mycelia as well as spores which can be released into the air. In conclusion, the present study showed an unexpectedly high number of diverse members of the class Actinobacteria in water damaged building material samples. However, possible health effects are not clear at present and deserve further detailed investigation.

\section{Acknowledgements}

We are grateful to all members of the institutes working on this project. Thanks are due to Dr. Lorenz, Institut für Innenraumdiagnostik, Düsseldorf for sample collection. We also thank Dr. I. Dill and Dr. Ch. Trautmann from the Institut Umweltmykologie GbR, Berlin, Dr. T. Gabrio and U. Weidner from Landesgesundheitsamt BadenWürttemberg, Regierungspräsidium Stuttgart, as well as I. Groth and K. Martin from Leibniz-Institut für Naturstoff-Forschung und Infektionsbiologie e.V. Hans-Knöll-Institut, Jena for excellent work in sample preparation and isolation of pure cultures. The study was supported by the Federal Environment Agency (Umweltbundesamt), grant number FKZ 20562236.

\section{Appendix A. Supplementary data}

Supplementary data associated with this article can be found, in the online version, at doi:10.1016/j.syapm.2010.04.006.

\section{References}

[1] Altenburger, P., Kämpfer, P., Makristathis, A., Lubitz, W., Busse, H.-J.(1996) Classification of bacteria isolated from a medieval wall painting. J. Biotechnol. 47, sification $39-52$.

[2] Andersson, M. (1999) Bacterial diversity and toxicity in air, indoor environment and foods. Dissertation, Ph.D. thesis, University of Helsinki, Finland. 
[3] Andersson, M.A., Mikkola, R., Kroppenstedt, R.M. (1998) The mitochondrial toxin produced by Streptomyces griseus strains isolated from an indoor environment is valinomycin. Appl. Environ. Microbiol. 64, 4767-4773.

[4] Andersson, M.A., Nikulin, M., Köljalg, U., et al. (1997) Bacteria, molds, and toxins in water damaged building materials. Appl. Environ. Microbiol. 63, 387-393.

[5] Andersson, M.A., Tsitko, I., Vuorio, R., Salkinoja-Salonen, M.S. (1999) Mycobacteria and related genera are major colonizers of a wall in a children's day care center. In: Johanning, E. (Ed.), Bioaerososols, Fungi and Mycotoxins: Health Effects, Assessment, Prevention and Control.

[6] Andersson, M.A., Weiss, N., Rainey, F., Salkinoja-Salonen, M.S. (1999) Dust borne bacteria in animal sheds, schools and children's day care centres. J. Appl. Microbiol. 86, 622-634.

[7] Beckett, W., Kallay, M., Sood, A., Zuo, Z., Milton, D. (2005) Hypersensitivity pneumonitis associated with environmental Mycobacteria. Environ. Health Perspect. 113, 767-770.

[8] Bornehag, C.-G., Blomquist, G., Gyntelberg, F., Järvholm, B., Malmberg, G.P., Nordvall, L., Nielsen, A., Pershagen, G., Sundell, J. (2001) Dampness in buildings and health nordic interdisciplinary review of the scientific evidence on associations between exposure to "Dampness" in buildings and health effects (NORDDAMP). Indoor Air 11, 72-86.

[9] Embil, J. Warren, P., Yakrus, M., Stark, R., Corne, S., Forrest, D., Hershfield, E. (1997) Pulmonary illness associated with exposure to Mycobacterium avium complex in hot tub water-hypersensitivity pneumonitis or infection. Chest 111, 813-816.

[10] Fischer, G., Hollbach, N., Schmitz, C., Dott, W. (2005) Luftgetragene Schimmelpilze in der Umwelt des Menschen - gesundheitliche Relevanz und Möglichkeiten der Risikobewertung. Gefahrst. - Reinhalt. Luft 65 (9 S), 335-340.

[11] Gauze, G.F., Preobrazhenskaya, T.P., Sveshnikova, M.A., Terekova, L.P., Maksimova, T.S. 1983 Opredelitel'Aktinomycetov. Rody Streptomyces, Streptoverticillium, Chainia, Izd. Nauka, Moscow (in Russian).

[12] Górny, R.L. (2004) Filamentous microorganisms and their fragments in indoor air-a review. Ann. Agric. Environ. Med. 11, 185-197.

[13] Haverinen, U., Husman, T., Pekkanen, J., Vahteristo, M., Moschandreas, D. Nevalainen, A. (2001) Characteristics of moisture damage in houses and their association with self-reported symptoms of the occupants. Indoor Built Environ. 10, 83-94.

[14] Hirvonen, M.-R., Huttunen, K., Roponen, M. (2005) Bacterial strains from moldy buildings are highly potent inducers of inflammatory and cytotoxic effects. Indoor Air 15, 65-70.

[15] Hirvonen, M.-R., Ruotsalainen, M., Savolainen, K., Nevalainen, A. (1997) Effect of viability of actinomycete spores on their ability to stimulate production of nitric oxide and reactive oxygen species in RAW264.7 macrophages. Toxicology 124 (2), 105-114.

[16] Huttunen, K., Jussila, J., Hirvonen, M.-R., Iivanainen, E., Katila, M.-L. (2001) Comparison of mycobacteria induced cytotoxity and inflammatory response in human and mouse cell lines. Inhal. Toxicol. 13, 977-991.

[17] Hyvärinen, A., Meklin, T., Vepsäläinen, A., Nevalainen, A. (2002) Fungi and actinobacteria in moisture-damaged building materials-concentrations and diversity. Int. Biodeterior. Biodegrad. 49, 27-37

[18] Jaakkola, M.S., Nordman, H., Piipari, R., Uitti, J., Laitinen, J., Karjalainen, A., Hahtola, P., Jaakkola, J.J.K. (2002) Indoor dampness and molds and development of adult-onset asthma: a population-based incident case-control study. Environ. Health Perspect. 110, 543-547.

[19] Janssen, P.H. (2006) Identifying the dominant soil bacterial taxa in libraries of $16 \mathrm{~S}$ rRNA and 16S rRNA genes. Appl. Environ. Microbiol., 1719-1728.

[20] Jussila, J., Komulainen, H., Huttunen, K., Roponen, M., Hälinen, A., Hyvärinen, A., Kosma, V.-M., Pelkonen, J., Hirvonen, M.-R. (2001) Inflammatory response in mice after intratracheal instillation of spores of Streptomyces californicus isolated from indoor air of a mouldy building. Toxicol. Appl. Pharmacol. 171, 61-69.

[21] Jussila, J., Komulainen, H., Huttunen, K., Roponen, M., Iivanainen, E., Torkko, P., Kosma, V.-M., Pelkonen, J., Hirvonen, M.-R. (2002) Mycobacterium terrae isolated from indoor air of a moisture-damaged building induces sustained biphasic inflammatory response in mouse lungs. Environ. Health Perspect. 110, 1119-1125.

[22] Kagen, S.L., Fink, J.N., Schlueter, D.P., Kurup, V.P., Fruchtman, R.B. (1981) Streptomyces albus: a new cause of hypersensitivity pneumonitis. J. Allergy Clin. Immunol. 68, 295-299.

[23] Kämpfer, P., Schäfer, J., Lodders, N., Busse, H.-J. (2010) Brevibacterium sandarkinum sp. nov., isolated from a wall of an indoor environment. Int. J. Syst. Evol. Microbiol. 60, 909-913.

[24] Kämpfer, P., Martin, K., Schäfer, J., Schumann, P. (2009) Kytococcus aerolatus sp. nov., isolated from indoor air in a room colonized with moulds system. Appl. Microbiol. 32, 301-305.

[25] Kämpfer, P., Schäfer, J., Lodders, N., Martin, K. (in press) Microlunatus parietis sp. nov., isolated from an indoor wall. Int. J. Syst. Evol. Microbiol. doi:10.1099/ijs.0.020115-0

[26] Kämpfer, P., Dreyer, U., Neef, A., Dott, W., Busse, H.-J. (2003) Chryseobacterium defluvii sp. nov., isolated from wastewater. Int. J. Syst. Evol. Microbiol. 53, 93-97.

27] Kämpfer, P., Schäfer, J., Lodders, N., Martin, K. (in press) Murinocardiopsis flavida gen. nov., sp. nov., a novel actinomycete isolated from indoor walls. Int. J. Syst. Evol. Microbiol., doi:10.1099/ijs.0.015990-0.

[28] Lacey, J., Crook, B. (1988) Fungal and actinomycete spores as pollutants of the workplace and occupational allergens. Ann. Occup. Hyg. 32 (4), 515-533.
[29] Lane, D.J. (1991) 16S/23S rRNA sequencing. In: Stackebrandt, E., Goodfellow, M. (Eds.), Nucleic Acid Techniques in Bacterial Systematics, John Wiley \& Sons, Inc., New York, NY, pp. 115-148.

[30] Lorenz, W., Trautmann, C., Dill, I. (2003) Nachweis und Bedeutung von Actinomyceten und sonstigen Bakterien in Innenräumen. Handbuch für Bioklima (Hrsg. Moriske, Turowski), Kap. III-4.4.14 ecomed Verlag, Landsberg am Lech, 10. Erg. Lfg, 12/2003.

[31] Lorenz, W., Kroppenstedt, R.M., Trautmann, C., Stackebrandt, E., Dill, I. (2003) Actinomycetes in building materialsL. In: International Conference Healthy Buildings, Singapore, pp. 583-589.

[32] Lorenz, W., Trautmann, C., Kroppenstedt, R.M., Sigrist, G., Stackebrandt, E., Gareis, M., Dill, I., Virnich, L. (2002) Actinomycetes in mouldy houses, the causative agent of rheumatoid symptoms? In: Proceedings of the 9th International Conference on Indoor Air Quality and Climate-Indoor Air 02, Monterey Indoor Air 4, 58-63.

[33] Martin, K., Schäfer, J., Kämpfer, P. (2010) Promicromonospora umidemergens sp. nov., isolated from moisture from indoor wall material. Int. J. Syst. Evol. Microbiol. 60, 537-541.

[34] McNeil, M.M., Brown, J.M. (1994) The medically important aerobic actinomycetes: epidemiology and microbiology. Clin. Microbiol. 7 (3), 357-417.

[35] Mehrer, A., Lorenz, W., Gareis, M., Trautmann, C., Kroppenstedt, R.M., Stackebrandt, E. (2003) Cytotoxicity of different actinomycetes isolated from building materialsL. In: 5th International Conference on Bioaerosols, Fungi, Bacteria, Mycotoxins and Human Health, Saratoga Spring, NY, USA.

[36] Minder, S., Nicod, L.P. (2005) Exogen allergische Alveolitis (Hypersensitivitätspneumonitis). Schweiz Med. Forum 5, 567-574.

[37] Nevalainen, A., Pasanen, A.-L., Niininen, M., Reponen, T., Kalliokoski, P., Jantunen, M.J. (1991) The indoor air quality in Finnish homes with mold problems. Environ. Int. 17, 299-302.

[38] Peltola, J. (2001) Microbial growth in building materials and toxigenic microbes in indoor environment. Dissertation, Ph.D. thesis, University of Helsinki, Finland.

[39] Peltola, J.S.P., Andersson, M.A., Kämpfer, P., Auling, G., Kroppenstedt, R.M., Busse, H.-J., Salkinoja-Salonen, M.S., Rainey, F.A. (2001) Isolation of toxigenic Nocardiopsis strains from indoor environments and description of two new Nocardiopsis species, N. exhalans sp. nov. and N. umidischolae sp. nov. Appl. Environ. Microbiol. 67, 4293-4304.

[40] Prauser, H., Falta, R. (1968) Phagensensibilität, Zellwand-Zusammensetzung und Taxonomie von Actinomyceten. Z. Allg. Mikrobiol. 8, 39-46.

[41] Rintala, H., Nevalainen, A., Suutari, M. (2002) Diversity of streptomycetes in water damaged building materials based on 165 rDNA sequences. Appl. Microbiol. 34, 439-443.

[42] Rintala, H., Pitkäranta, M., Toivola, M., Paulin, L., Nevalainen, A. (2008) Diversity and seasonal dynamics of bacterial community in indoor environment. BMC Microbiol. 8, 56.

[43] Roponen, M., Toivola, M., Meklin, T., Ruotsalainen, M., Komulaine, H, Nevalainen, A., Hirvonen, M.-R. (2001) Differences in inflammatory responses and cytotoxicity in RWA 264.7 macrophages induced by Streptomyces anulatus grown on different building materials. Indoor Air 11, 179-184.

[44] Sambrook, J., Russel, D.W. 2001 Molecular Cloning, A Laboratory Manual, Volume 1, 3. Auflage, Cold Spring Harbor Laboratory Press, New York.

[45] Schäfer, J., Busse, H.-J., Kämpfer, P. (2009) Pseudonocardia parietis sp. nov., from the indoor environment. Int. J. Syst. Evol. Microbiol. 59, 2449-2452.

[46] Schäfer, J., Martin, K., Kämpfer, P. (2010) Citricoccus parietis sp. nov., isolated from a mould-colonized wall, and emended description of Citricoccus alkalitolerans Li et al. 2005. Int. J. Syst. Evol. Microbiol. 60, 271-274.

[47] Schäfer, J., Martin, K., Kämpfer, P. (2010) Prauserella muralis sp. nov., from an indoor environment. Int. J. Syst. Evol. Microbiol. 60, 287-290.

[48] Schwieger, F., Tebbe, Ch.C. (1998) A new approach to utilize PCR-single-strandconformation polymorphism for 16S rRNA gene-based community analysis. Appl. Environ. Microbiol. 64, 4870-4876.

[49] Shirling, E.B., Gottlieb, D. (1966) Methods for characterization of Streptomyces species. Int. J. Syst. Bacteriol. 16, 313-340.

[50] Spengler, J., Neas, L., Nakai, S., Dockery, D., Speizer, F., Ware, J., Raizenne, M (1994) Respiratory symptoms and housing characteristics. Indoor Air 4, 72-82

[51] Stach, JE.M. Maldonado LA, Ward, A.C Goodfellow, M. Bull, A.T (2003) New primers for the class Actinobacteria: application to marine and terrestrial environments. Environ. Microbiol. 5 (10), 828-841.

[52] Suihko, M.-L., Priha, O., Alakomi, H.-L., Thompson, P., Mälarstig, B., Stott, R Richardson, M. (2009) Detection and molecular characterization of filamentous actinobacteria and thermoactinomycetes present in water-damaged building materials. Indoor Air 19, 268-277.

[53] Sundell, J., Lindvall, T., Stenberg, B., Wall, S. (1994) Sick building syndrome (SBS) in office workers and facial skin symptoms among VDT-workers in relation to building and room characteristics: two case-referent studies. Indoor Air 4 83-94.

[54] Szewzyk, R. (2008) Gesundheitsgefährdung durch Schimmelpilze. Gefahrstoffe- Reinhaltung der Luft 9, 345.

[55] Tamura, K., Dudley, J., Nei, M., Kumar, S. (2007) MEGA4: Molecular Evolutionary Genetics Analysis (MEGA) software version 4.0. Mol. Biol. Evol. 24, 1596-1599.

[56] Technische Regeln für Biologische Arbeitstoffe, Einstufung von Bakterien (Bacteria) und Archaebakterien (Archaea) in Risikogruppen Bundesarbeitsblatt 7-2006, 33-193.

[57] Torvinen, E., Meklin, T., Torkko, P., Suomalainen, S., Reiman, M., Katila, M.-L Paulin, L., Nevalainen, A. (2006) Mycobacteria and fungi in moisture-damaged building materials. Appl. Environ. Microbiol. 72, 6822-6824. 
[58] Vuorio, R., Andersson, M.A., Rainey, F.A., Kroppenstedt, R.M., Kämpfer, P. Busse, H.-J., Viljanen, M., Salkinoja-Salonen, M.S. (1999) A new rapidly growing mycobacterial species. Mycobacterium murale sp. nov., isolated from the indoor walls of a children's day care center. Int. J. Syst. Bacteriol. 49, 25-35.

[59] Weisburg, W.G., Barns, S.M., Pelletier, D.A., Lane, D.J. (1991) 16 S ribosomal DNA amplification for phylogenetic study. J. Bacteriol. 173 (2), 697-704.
[60] Zada, B., Hahn, D., Chatzinotas, A., Schönhuber, W., Neef, A., Amann, R.I., Zeyer, J. (1997) Analyses of bacterial community structure in bulk soil by in situ hybridization. Arch. Microbiol. 168, 185-192. 